\title{
Pre-eighteenth-century traditions of revivalism: Damascus in the thirteenth century
}

\author{
KONRAD HIRSCHLER * \\ Universität Kiel
}

\section{Introduction}

The revivalist movements in Islamic countries during the eighteenth and nineteenth centuries are of special interest in the history of reform and opposition there. As increasing European penetration did not yet play a salient role, these revivalists acted largely within an endogenous system of reference. In contrast, nineteenth-century modernists, such as al-Afghānī (d. 1897) and Muhammad 'Abduh (d. 1905) had to consider the degree to which they should emulate European models in such important matters as administration, education and law.

Revivalist movements have been increasingly subject to research within the framework of the general trend to study the hitherto neglected eighteenth century more intensively. ${ }^{1}$ Among the most important personalities in these movements were Shāh Wali Allāh (d. 1766) on the South Asian subcontinent, Muhammad b. 'Abd al-Wahhāb (d. 1792) on the Arabian peninsula, Muḥammad b. 'Alī al-Shawkānī (d. 1834) in Yemen and Muhammad b. 'Alī al-Sanūsī (d. 1859) in North Africa.

However, while a more informed picture of their ideas and convictions is slowly emerging, the historicity of these ideas remains under-researched. It is unclear how far crucial elements were based on a complete reworking of existing concepts or were taken up from preceding traditions of reform and revival. Although the roots of present-day revivalism have been established in the eighteenth- and nineteenth-century movements, ${ }^{2}$ these movements themselves seem to have emerged mainly out of an intellectual void. It is therefore

* I would like to express my thanks to the anonymous reviewer, Ulrike Freitag, Michael Brett, Achim Rohde and Edwin Towill who read drafts of this article at different stages and pointed out flaws from minor to major. Earlier versions of this paper were presented at the XI Colloquium on the History of Egypt and Syria in the Fatimid, Ayyubid and Mamluk Eras, Leuven, 16/17 May 2002 and at the First World Congress for Middle Eastern Studies, Mainz 8-13 September 2002. Those present helped me, through their comments and questions, to rethink aspects of the argumentation. Thanks to Stefan Sperl, Bernard A. Haykel, Knut S. Vikør and Guido Steinberg who provided me with information on specific issues.

${ }^{1}$ The more intensive study of the eighteenth century initially started with a rejection of the idea of decline in the post-formative Islamic lands, best represented by R. Owen, "The Middle East in the eighteenth century - an "Islamic" society in decline: a critique of Gibb and Bowen's Islamic Society and the West', in Review of Middle Eastern Studies 1 1975: 101-12. This development was subsequently partly burdened by discussions of attempts such as those by P. Gran, Islamic Roots of Capitalism, Egypt 1740-1840, second edition (Austin and London, 1998) to detect capitalist roots or by R. Schulze, 'Das Islamische Achtzehnte Jahrhundert. Versuch einer historiographischen Kritik', in Die Welt des Islams 30, 1990: 140-59 to find traces of an Islamic Enlightenment. The latter article was the starting point for a long-lasting discussion conducted almost exclusively in German. It has turned extremely polemical as in, for example, B. Radtke, Autochtone islamische Aufklärung im 18. Jahrhundert: theoretische und filologische Bemerkungen. Fortführung einer Debatte (Utrecht, 2000). Even so, the number of studies on the eighteenth century has increased during the last two decades and for the present article, studies such as N. Levtzion and J.O. Voll (eds), Eighteenth-Century Renewal and Reform in Islam, (Syracuse, NY, 1987) have been important starting points.

${ }^{2}$ J.O. Voll, 'Renewal and reform in Islamic history: Tajdid and Islah', in J. Esposito (ed.), Voices of Resurgent Islam (New York and Oxford, 1983), 32-47, at 44. E. Sivan, Radical Islam. Medieval Theology and Modern Politics (New Haven and London, 1985) discusses in some detail the role of medieval writings in present-day revivalism.

Bulletin of SOAS, 68, 2 (2005), 195-214. (C) School of Oriental and African Studies. Printed in the United Kingdom. 
necessary to study in more detail the historical precedents on which they drew for formulating their ideas. Having established that the eighteenth century is an important area for research, it now seems appropriate to enquire more thoroughly into continuities from preceding periods.

The present article examines from this perspective the issue of ijtihädltaqlìd, which featured prominently in eighteenth- and nineteenth-century revivalist thought. Taking the example of scholars in thirteenth-century Damascus, it firstly compares the respective readings of ijtihädltaqlìd, by focusing on one individual, Abū Shāma (d. 1267). Secondly, it asks whether a scholar such as Abū Shāma, who had adopted a reading similar to that of later revivalists, also took a critical and oppositional stand against large sections of contemporary society, i.e. a revivalist posture. It is this article's main contention that the example of Abū Shāma shows the need for more detailed study of possible revivalist traditions prior to the 'grand' movements. The combination of the history of ideas and social history might allow a deeper understanding of how and in what contexts calls for reform and opposition to the current state of affairs were expressed. The role of Abū Shāma will be discussed in the following as one specific case study, without intending to ascribe an outstanding and unique role to this average scholar of thirteenth-century Damascus.

\section{Revivalism and ijtihād: general considerations}

The term 'revivalist movements' for the eighteenth and nineteenth centuries does not refer to a closely connected group of movements that can easily be given a single label. Indeed, the idea that the different groups shared any unifying themes has in recent years been dismissed out of hand: the differences in terms of social context and spiritual reference systems out of which they arose would not permit such a designation. ${ }^{3}$ However, this argument sidelines such unifying elements as a shared emphasis on the study of hadit $h^{4}$ or personal connections between prominent figures via loose networks of shared teachers. ${ }^{5}$ Furthermore, recently published studies on some of the protagonists underline in detail the similarities among the revivalist groups of this period. ${ }^{6}$

'Revivalism' is understood here as a stance that formulates its critique of the contemporary state of affairs in terms of a return to an idealized early Islamic period. Such a reference system is not unusual for individuals striving for change in societies that adhere predominantly to religions of revelation. The most outstanding example in Latin Christendom would be the Reformation of the sixteenth and seventeenth centuries. ${ }^{7}$ Within the Islamic world these references had been, and have continued to be, an important framework for individuals and groups seeking to transform their societies. Revivalist thought is characterized by a shared basis of three crucial elements: a call for a return to Quran and sunna; a reaffirmation of authenticity especially vis-à-vis syncretistic tendencies; and an emphasis on the need to apply ijtihād. ${ }^{8}$ A position

${ }^{3}$ A. Dallal, 'The origins and objectives of Islamic revivalist thought, 1750-1850', in Journal of the American Oriental Society 113 1993: 341-59.

${ }^{4}$ N. Levtzion and J.O. Voll, 'Introduction', in Levtzion and Voll, Eighteenth-Century, 3-20.

${ }^{5}$ J.O. Voll, 'Linking groups in the networks of eighteenth-century revivalist scholars. The Mizjaji family in Yemen', in Levtzion and Voll, Eighteenth-Century, 69-92.

${ }^{6}$ For example, studies on al-Sanūsĩ: K.S. Vikør, Sufi and Scholar on the Desert Edge. Muhammad b. 'Alī al-Sanūsī and his Brotherhood (London, 1995); or on al-Shawkānī: B.A. Haykel, Revival and Reform in Islam. The Legacy of Muhammad al-Shawkānì (Cambridge, 2003).

${ }^{7}$ R. Peters, 'Erneuerungsbewegungen im Islam vom 18. bis zum 20. Jahrhundert und die Rolle des Islams in der neueren Geschichte: Antikolonialismus und Nationalismus', in W. Ende and U. Steinbach (eds), Der Islam in der Gegenwart, fourth edition, (Munich, 1996), 90-128, at 90.

${ }^{8}$ Voll, 'Renewal and Reform', 35-43. 
opposed to revivalism is described here as 'traditionalist'; this term refers to segments of society that reject the critique of the existing state of affairs by stressing the need for continuing established praxis. ${ }^{9}$ These individuals reject, for instance, the wide-ranging revivalist understanding and application of ijtihād.

In Sunni Islam, ijtihād referred to the "total expenditure of effort in seeking an opinion regarding a rule of divine law such that the one [putting forth the effort] senses within himself an inability to do more [than he has done]'. ${ }^{10}$ Differentiated from ijtihäd was taqlìd, the following of a legal decision taken by a jurist of a later period without necessarily having an understanding of the process of discovering/developing the rule. Until the 1980s it was generally assumed that the application of ijtihād in Sunni Islam had disappeared after the ninth century with the formation of the law schools (madhhabs), after which taqlid gained a dominant position; in Schacht's famous words 'the closing of the door of ijtihäd'. ${ }^{11}$ In the last two decades this position has been vehemently criticized in a number of revisionist studies, which argue that ijtihād continued to be practised in subsequent centuries. ${ }^{12}$ Scholarship has shown that although certain groups within Islamic societies rejected it, there was never a consensus on this issue.

In recent years a middle position has emerged, which argues - against the revisionist position - that ijtihād as meaning unmediated access to the revealed sources $^{13}$ did generally stop. According to this position, the continuation of ijtihād referred merely to lower degrees of ijtihād, in the sense of interpretative thinking within the established scholarly canon. ${ }^{14}$ In the post-formative (or

${ }^{9}$ This understanding of traditionalism differs from that of R.C. Martin, M.R. Woodward and D.S. Atmaya, (Defenders of Reason in Islam (Oxford, 1997), 13ff.), who refer to the position of preserving the status quo as 'traditional'. 'Traditionalist', in their definition, refers to the stance of criticizing the present with reference to an idealized past. They see traditionalist as being opposed to 'rationalist', i.e. the attempt to articulate the message of Islam within any given age's contemporary intellectual and social trends.

10 'A. al-Āmidī, Kitāb al-ihkām fì ușūl al-ahkām, ed. S. al-Jumaylī, 4 vols in 2, (Beirut, 1984), 4: 169 (paraphrased in B.G. Weiss, The Search for God's Law. Islamic Jurisprudence in the Writings of Sayf al-Dīn al-Ämidī (Salt Lake City, 1992), 693.

${ }_{11}$ J. Schacht, An Introduction to Islamic Law (Oxford, 1964), 71. This understanding has been so wide-spread that non-Arabist writers in neighbouring fields have been led to the misunderstanding that ijtihäd itself means the 'closing of the gate' of interpretation, see for example J. Assmann, Das kulturelle Gedächtnis. Schrift, Erinnerung und politische Identität in frühen Hochkulturen (Munich, 1992), 208.

${ }^{12}$ W.M. Watt, 'The Closing of the Door of iğtihād', in J.M. Barral (ed.), Orientalia Hispanica sive studia F.M. Pareja octogenario dicata, 2 vols. (Leiden, 1974), Arabica-Islamica, 1: 674-8 and B. Weiss, 'Interpretation in Islamic law: the theory of ijtihād', in The American Journal of Comparative Law 26, 1978: 199-212 express early scepticism about Schacht's view. The decisive revision was undertaken by W.B. Hallaq, most importantly W.B. Hallaq, 'Was the Gate of ijtihād closed?', in International Journal of Middle East Studies 16 (1984): 3-41, and W.B. Hallaq, 'On the origins of the controversy about the existence of mujtahids and the gate of ijtihād', in Studia Islamica 63, 1986: 129-141. This debate is subject to the descriptive article by S.P Ali-Karamali and F. Dunne, 'The ijtihad controversy', in Arab Law Quarterly 9, 1994: 238-57.

${ }_{13}$ The totality of the words and deeds of the Prophet, the sunna, as exemplified in the hadiths, does not technically constitute a revealed source, theoretically limited to the Quran. However, praxis in later centuries tended to ascribe a similar authoritative status to both. 'Revealed sources' is used here in this sense.

${ }^{14}$ N. Calder, 'Al-Nawawi's typology of muftiss and its significance for a general theory of Islamic law', in Islamic Law and Society 3, 1996: 137-64 and S.A. Jackson, Islamic Law and the State. The Constitutional Jurisprudence of Shihāb al-Dìn al-Qaräfì (Leiden, 1996), $73 \mathrm{ff}$.

H. Gerber, in Islamic Law and Culture, 1600-1840, (Leiden, 1999) sets out to challenge their arguments by discussing the continued application of ijtihād during the Ottoman period. However, his discussion refers mainly to examples that support the view that ijtihād was not applied to the revealed sources except in the limited number of cases where no solution existed. 
'post-classical') period, the highest rank of mujtahid mustaqill (independent mujtahid) or mujtahid mutlaq (unrestricted mujtahid) was retrospectively limited to companions of the Prophet and the founders of the madhhabs. Mujtahids of later centuries, in contrast, were considered able merely to attain lower ranks such as mujtahid fi al-madhhab (limited to decision within one specific madhhab) and mujtahid muqayyad (restricted mujtahid). ${ }^{15}$ Thus, according to this middle position, the gate of ijtihād in its classical sense was indeed closed, while a 'minor' ijtihād continued to be applied. As will be shown in the following discussion of thirteenth-century ijtihâd, this middle position takes too restricted a view of the application of ijtihâd in the post-formative period. Ijtihâd continued to be understood by segments of the scholarly community as the process of finding a rule of law by way of direct and unmediated access to the revealed sources.

\section{Eighteenth- and nineteenth-century revivalism: the issue of ijtihād}

The embracing of ijtihād as well as the opposition to taqlìd and school factionalism turned out to be one of the cornerstones of the thinking of the eighteenth- and nineteenth-century revivalists. ${ }^{16}$ The disregard for later authorities, and the need to access the revealed sources directly, resonated strongly in their works. Unlike other elements in their thinking, such as the issue of Sufism, ${ }^{17}$ the state of knowledge on the historicity of the revivalists' claim for ijtihād is still unstudied. Modern studies refer almost without exception briefly to Ibn Taymiyya (d. 1328) as the intellectual forefather in this regard, or include some unspecific comments. ${ }^{18}$

This lack of knowledge is the more surprising as the revivalists themselves put their claim in a historical perspective. Al-Shawkānī, for example, introduced his biographical dictionary on eminent personalities after the thirteenth

${ }^{15}$ A. Poya, "Iğtihād" und Glaubensfreiheit. Darstellung einer islamisch-glaubensfreiheitlichen Idee anhand sunnitisch-rechtsmethodologischer Diskussionen', in Der Islam 75, 1998: 226-58, at $229 \mathrm{f}$.

${ }^{16}$ In general: R. Peters, 'Idjtihād and taqlīd in $18^{\text {th }}$ and $19^{\text {th }}$ century Islam', in Die Welt des Islams 20, 1980: 131-45; Voll, 'Renewal and Reform', 37ff.; and K.S. Vikør, 'The development of ijtihad and Islamic reform', paper held at Third Nordic Conference on Middle Eastern Studies, Joensuu/Finland, 19-22 June 1995 (www.hf.uib.no/smi/paj/vikor.html). More specifically for al-Shawkānī: Haykel, Revival and Reform; for al-Sanūsī: Vikør, Sufi and Scholar, 220ff.; for Shāh Walī Allāh: M.A. 'Ali, 'A critical evaluation of Shāh Walì Allāh's attitude to ijtihād vis-à-vis the views of the other jurists', in Hamdard Islamicus 20, 1997: 19-26.

${ }^{17}$ See for example A. Knysh, 'Ibrāhīm al-Kūrānī (d. 1101/1690), an apologist for waḥdat al-wujūd', in Journal of the Royal Asiatic Society 5 (N.S.), 1995: 39-47. For a study on the defence of Ibn 'Arabì by al-Kūrānī (d. 1690), one of the important figures in the scholarly genealogy of Shāh Walī Allāh and Ibn 'Abd al-Wahhāb, see J.O. Voll, Muḥammad Hayyā al-Sindī and Muhammad Ibn 'Abd al-Wahhāb, 'An analysis of an intellectual group in eighteenth-century Madina', in Bulletin of the School of Oriental and African Studies 38, 1975: 32-9.

${ }^{18}$ For example F. Rahman, 'Revival and reform in Islam', in P.M. Holt, A.K.S. Lambton and B. Lewis (eds), The Cambridge History of Islam, 2. vols. (Cambridge, 1970), 632-56; Levtzion and Voll, 'Introduction', esp. 13; Vikør, 'Development of ijtihad'. The more detailed studies of Vikør, Sufi and Scholar and Haykel, Revival and Reform refer at least to the respective teachers of al-Sanūsī and al-Shawkānī who played a crucial role in this regard. K.S. Vikør, Muhammadan Piety and Islamic Enlightenment: Survey of a Historiographical Debate, paper presented at ISMM Workshop Istanbul 1998, 17ff., discusses al-Sanūsîs teacher Ibn Idris in more detail. G. Steinberg, Religion und Staat in Saudi-Arabien: die wahhabitischen Gelehrten, 1902-1953 (Würzburg, 2002), discusses the significance of the different traditions of Ibn Taymiyya and Ibn Qudāma in the context of the Wahhābi movement from the eighteenth to the twentieth centuries. The comment by Peters, 'Erneuerungsbewegungen', 144f., that the problem in general deserves more detailed study is still accurate. The same holds true for the historicity of present-day revivalism. Even a work such as Sivan, Radical Islam considers the importance of Ibn Taymiyya only with regard to issues such as jihād, and sidelines ijtihād. 
century specifically with the need to refute the idea that ijtihād had ceased to exist and was inappropriate for later periods:

The tongues of a group of people belonging to the riff-raff spread the opinion that the forefathers of this community alone have precedence in the field of knowledge at the exclusion of their successors. This went so far that some of the people belonging to the four schools made public that it is impossible to find mujtahids after the sixth century [twelfth century] or after the seventh century [thirteenth century] as others have claimed. ${ }^{19}$

The dictionary subsequently presented an extended statement of his claim that $i j t i h \bar{a} d$ was a continuous reality in all periods of Islamic history by including a large number of biographies on mujtahids. Al-Shawkānī focused particularly on the Yemeni tradition in order to set forth his claim for ijtihād in this local setting. The North African scholar al-Sanūsī also referred to previous mujtahids in his main work on ijtihād. ${ }^{20}$ In the first part he listed twelve mujtahids of the fourteenth and fifteenth centuries who were little-known and rather minor scholars. ${ }^{21}$ All of them originated from the western Islamic lands and belonged to the Māliki school. Like al-Shawkānī, al-Sanūsī placed himself in a local continuous tradition of mujtahids.

However, al-Sanūsī did not limit himself to this local tradition, but in the second part went on to name ten mujtahids based in thirteenth- and fourteenthcentury Damascus and Cairo who belonged mostly to the Shāfi'i school. ${ }^{22} \mathrm{He}$ started the list with the Damascene scholar Ibn 'Abd al-Salām (d. 1262) and included the latter's students Ibn Daqīq al-'Īd (d. 1302) and Abū Shāma. Interestingly, in one of his works al-Shawkānī included a similar list of mujtahids beyond his local setting, too.

Starting once again with Ibn 'Abd al-Salām, he constructed a continuity of mujtahids stretching from the thirteenth century, via Ibn Daqĩ al-' $\bar{I} d$, to the early sixteenth century with al-Suyūtī (d. 1505), the Egyptian 'mujaddid'. ${ }^{23}$ Ibn 'Abd al-Salām was also named in the writings of other revivalists such as Shāh Wali Allāh, who tried to prove the continuous ijtihād tradition up to his own day..$^{24}$

Thus eighteenth- and nineteenth-century revivalists were not only aware of the respective local ijtihād tradition, but also of an ijtihād tradition centred on the Shâfi'i community in Damascus and Cairo beginning in the thirteenth century. The reference to the same tradition by different writers shows its importance for their claim for ijtihād.

${ }^{19}$ M. al-Shawkānī, Al-Badr al-țāli` bi-mahāsin man ba'da al-qarn al-sābi', ed. H. al-'Amrī (Beirut, 1998), 23: 'shā'a 'alā alsun jamā' a min al-ra' à' ikhtișās salaf hādhihī al-umma bi-ihrāz fadìlat al-sabq fì al-ulūm dūn khalafihā hattā ishtahara 'an jamā'a min ahl al-madhāhib al-arba'a ta'adhdhur wujūd mujtahid ba'd al-mi'a al-sādisa ka-mā nuqila 'an al-ba'd aw ba'd al-mi'a al-sābi'a ka-mā za'amahū ākharūn'.

${ }^{20}$ M. al-Sanūsī, 'Īqāz al-wasnān fī al-‘amal bi-l-ḥadīth wa-l-Qur’ān', in al-Majmū'a al-mukhtāra, ed. n.n. (Manchester, 1990), 11-141, at 73f

${ }^{21}$ It was not possible to identify the two brothers 'Abd al-Raḥmān and 'Īsā b. Muhammad who 'died around 749'.

${ }^{22}$ With the exception of Ibn Taymiyya and Muhammad b. al-'Arabī (d. 1148), a Māliki from the western lands who stands out in this second part. The third part of the list refers to six individuals who claimed the rank of mujtahid, among them Ibn al-Ṣalāh and al-Suyūṭi (al-Sanūsī, 'Īqāz, 73f.)

${ }^{23}$ M. al-Shawkānī, Irshād al-fuhūl ilā tahqūq al-ḥaqq min 'ilm al-uṣūl, ed. n.n. (Cairo, 1937), 254.

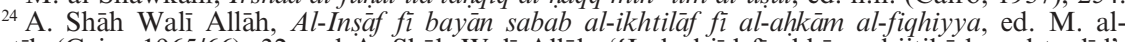
Khațīb (Cairo 1965/66), 32 and A. Shāh Walī Allāh, "Iqd al-jīd fì aḥkām al-ijtihād wa-l-taqlīd', trans. M.D. Rahbar, in The Muslim World 45, 1955: 346-58, at 358. 


\section{Thirteenth-century ijtihād and taqlīd: the example of Abū Shāma}

Abū Shāma, ${ }^{25}$ one of the individuals named in al-Sanūsı̄'s list, was a Damascene Shāfici scholar, best known for The Book of the Two Gardens, his chronicle of the reigns of Salāh al-Dīn and Nūr al-Dīn. ${ }^{26}$ Biographers of Abū Shāma repeatedly described him as having attained the rank of a mujtahid. ${ }^{27}$ This is surprising since his contribution to Islamic law (applied and theoretical) was rather modest. His fatwās have not come down to us, and his completed writings in applied and theoretical law were limited to three treatises. ${ }^{28}$ Being mujtahid, he found himself in the company of individuals with a decisively more important contribution to the juridical field, such as the above-named Ibn 'Abd al-Salām ${ }^{29}$ or Ibn Daqīq al- 'Īd. ${ }^{30}$ Nevertheless, Abū Shāma's appearance in the lists of eighteenth- and nineteenth-century revivalists might be explained by the unequivocal claim for, and defence of, ijtihäd expressed in his writings.

In his Mukhtasar al-mu'ammal fì al-radd ilā al-amr al-awwal (Summary of the Hopeful [Book] on the Restoration of the Original State) Abū Shāma laid out his understanding of ijtihäd in detail. In it he included a 'Section on the Duty of Having Recourse to the Qur'ān and the sunna. ${ }^{31}$ Here he argued that only consultation of the revealed sources could solve disputed matters. Other sources, such as rulings derived by ijmāa (consensus of scholars) or qiyās (reasoning by analogy) were mentioned in this text, only to be rejected: 'Reasoning by analogy is like the meat of an animal not slaughtered in accordance with ritual requirements - if you are in need of it, you take it'. ${ }^{32}$

He certainly did not completely disregard the opinions of such later authorities as the founders of the madhhabs, but referred to them in this section and elsewhere. However, he cited them mainly to support his view that there could not be any authority besides the revelation - that is to say, his

${ }^{25}$ On Abū Shāma see references in M. al-Dhahabī, Tārīkh al-Islām wa-wafayāt al-mashāhīr wa-l-a' làm, ed. 'U. 'Abd al-Salām Tadmurī, 52 vols. (Beirut, 1994-2000), years 661-670: 196 f.; in addition: Muhammad Ibn al-Jazarī, Ghāyat al-nihāya fì tabaqāt al-qurrǟ, ed. G. Bergsträsser and O. Pretzl, 3 vols. (Cairo, 1933-35), 1: $365 \mathrm{f}$. Among modern sources the following focus on his social and intellectual contexts: M.H.M. Ahmad, 'Studies on the works of Abu Shama 599-665 AH (1203-1267)', (PhD Dissertation, University of London, 1951); M.H.M. Ahmad, 'Dirāsa watahlīl', in M.H.M. Ahmad (ed.) Abū Shāma: Kitāb al-rawdatayn, (Cairo, 1956), I/1:1-57; L. Pouzet, 'Maghrébiens à Damas au VIIe/XIIIe siècle', in Bulletin d'Etudes Orientales 28, 1975: 167-99, at 170 ff.; L. Pouzet, 'Abu Shama (599-665/1203-1268) et la société Damascaine de son temps', in Bulletin d'Etudes Orientales 37/38, 1985/86: 115-26; Editor's introduction in T. Altıkulaç, Ebū Shāme el-Makdisī ve el-Murșid el-Veciz (Beirut, 1975).

${ }^{26}$ The most reliable edition is: 'A. Abū Shāma, Kitāb al-rawḍatayn fì akhbār al-dawlatayn al-Nūriyya wa-l-Salāhiyya, ed. I. al-Zībaq, 5 vols. (Beirut, 1997).

${ }^{27}$ M. al-Dhahabì, Tadhkirat al-huffäz, ed. n.n., 4 vols. (Haydarabad, 1915/16), 4: 243; 'A. al-Subkī, Țabaqāt al-Shāfi' iyya al-kubra, ed. M. al-Țanāhī and 'A. al-Hilw, 10 vols. (n.p., 1964' 76), 8: 165; I. Ibn Kathīr, al-Bidāya wa-l-nihāya fì al-tārīkh, ed. 'A. Ațwì et al., 15 vols. (Beirut, 1985), 13: 264.

${ }_{28}$ Al-Bă'ith 'alā inkār al-bidā' wa-l-hawādith, ed. 'U. A. 'Anbar (Cairo, 1978); al-Muhaqqaq min 'ilm al-uṣūl fima yata'allaqa bi-af'āl al-rusūl, ed. A. al-Kuwaytī (Amman, 1988) and Mukhtașar al-múammal fí al-radd ilā al-amr al-awwal, ed. Ș. M. Ahmad (Kuwait, no date [1983?]). In Abū Shāma's al-Dhayl 'alā al-rawdatayn (published as: Tarājim rijāl al-qarnayn al-sādis wa-l-sābi '), ed. M. al-Kawtharī (Cairo, 1947), 39/40 a list of non-completed titles of his is given. These include some which deal with law, such as al-urjüza fì al-fiqh, a didactic poem.

${ }_{29}^{2}$ Described as mujtahid in: al-Dhahabī, Tärîkh, years 651-660: 416 ff.; Kh. al-Safadī, al-Wāfi bi-l-wafayāt, ed. H. Ritter et al. (Istanbul \& others, 1931-97), 18: 520 ff.; 'A. al-Yāfi'ì, Mir'at al-Janän wa-'ibrat al-yaqzān, ed. n.n., 4 vols. (Haydarabad, 1919-21), 4: $153 \mathrm{ff}$.

${ }^{30}$ Described as mujtahid in: al-Dhahabī, Huffāz, 4: 262 f.; al-Ṣafadī, al-Wāfì, 4: 193 ff.; al-Subkī, Tabaqāt, 9: 207 ff.; 'A. al-Asnawì, Țabaqāt al-Shäfi' iyya, ed. 'A. Jibūrī, 2 vols. (Baghdad, 1970/71), 2: $227 \mathrm{ff}$

${ }^{31}$ Abū Shāma, al-Mu'ammal, 45 ff.: 'Faṣl fì wujūb al-rujū' ilā al-kitāb wa-l-sunna'.

${ }^{32}$ Ibid., 45 citing the hadìth scholar 'Āmir b. Sharāhịl al-Sha'bī (d. 721?): 'al-qiyās ka-l-mayta idhā ihtajjta ilayhā fa-sha'nuka bi-hä'. 
references to the acknowledged later authorities referred mainly to their understanding of ijtihād, and not to their concrete juridical decisions. ${ }^{33}$ Thus, 'alShāfi 'ì forbade [his students from] following himself or others [blindly]. ${ }^{34}$ Abū Shāma weakened the authority of any statement besides the revelation by arguing that no individual is faultless: 'It is not allowed for anyone to use the statement of a mujtahid as an argument as the mujtahid might be correct or might err' ${ }^{35}$ Consequently, no source except the revelation could be consulted for guidance.

He attacked his contemporaries for giving preponderance to later juridical writings such as those by Abū Ishāq al-Shīrāzī (d. 1083) and al-Ghazālì (d. 1111). It was the perceived acceptance of later authorities that induced Abù Shāma to compose this work in the hope of restoring 'the Original State' ${ }^{36}$ as he himself interpreted it. He could observe only with disgust the factionalism $\left(t a^{c} a s s u b\right)^{37}$ of the madhhabs and how for the followers 'the statements of their imams gained [...] the status of the two sources [Qur'ān and the sunna]'. ${ }^{38}$ At the same time he severely criticized his own Shāfi i madhhab for the doctrinal discrepancies and contradictory statements of its two 'tarìqas', the Iraqis and the Khurasanians. The adherents of these taríqas did not even consult the works of al-Shāfi'i directly, to say nothing of the revealed sources, but relied on later deviating transmissions. ${ }^{39}$ His two other juridical pieces ${ }^{40}$ similarly restated the importance of the Quran and sunna for legal decisions.

Abū Shāma did not limit himself to conceptualizing ijtihād in such broad terms; he also applied the concomitant methodology in his writings. His al$B \bar{a}$ 'ith 'alā inkār al-bida' wa-l-hawādith (Inducement to reject innovations and events) was a treatise on the salāt al-raghäib (prayer of supplications), which was performed on the first Friday of the lunar month of Rajab. This prayer was similar to the prayers of mid-Sha'bān that were accompanied by popular festivities in Damascus. ${ }^{41}$

From the early Islamic era Rajab had become widely accepted as a period of sanctity. Those following this practice, which was probably developed from pre-Islamic notions of sanctity, offered sacrifices, performed additional prayers, and also fasted..$^{42}$ The issue of salät al-raghä'ib had been the cause of conflict in Damascus when Ibn 'Abd al-Salām attempted to stop the practice in 1239-40 after his nomination as khațīb in the Umayyad mosque. ${ }^{43}$ However,

\footnotetext{
${ }^{33}$ For example ibid., 45 ff. and $57 \mathrm{ff}$.

${ }^{34}$ Ibid., 47: 'nahā al-Shāfi ${ }^{\top} \bar{\imath}$ 'an taqlìdihì wa-taqlìd ghayrihì'.

${ }^{35}$ Ibid., 39: 'là yajūzu li-ahad an yahtajja bi-qawl al-mujtahid li-anna al-mujtahid yukhtị'u wa-yusīibu'.

${ }^{36}$ His references to the 'original state' of the Prophet Muhammad were closely linked to the increasing veneration of the Prophet in Egypt and Syria in his period (on the Prophet's veneration see L. Pouzet, Damas au VIIelXIIe Siècle. Vie et Structures Religieuses d'une Métropole (Beirut, 1988), 357-8). While this veneration was commonplace in his time, Abū Shāma was among those individuals who considered the Prophet's period not a distant ideal, but a concrete alternative to the present state of affairs. On Abū Shāma's historical outlook see my PhD thesis, 'Narrating the past: social contexts and literary structures of Arabic historical writing in the seventh/thirteenth century', (University of London (SOAS), 2003), ch. 5.

${ }^{37}$ Ibid., 42.

${ }^{38}$ Ibid., 41: 'șārat aqwāl a'immatihim 'indahum bi-manzalat al-așlayn'.

${ }^{39}$ Ibid., 47-8.

${ }^{40}$ Abū Shāma, al-Bācith and al-Muhaqqaq.

${ }^{41}$ On these prayers, M.J. Kister, "Rajab is the month of God..." a study in the persistence of an early tradition', in Israel Oriental Studies 1, 1971: 191-223; Pouzet, Damas, 343 ff. and M. Fierro, 'The treatises against innovations (Kutub al-bida')', in Der Islam 69, 1992: 204 46, at 226 .

${ }^{42}$ On the outstanding status of Rajab see Kister, 'Rajab'.

${ }^{43}$ Al-Subkī, Tabaqāt, 8: 251 ff. who cites also the relevant fatwās.
} 
the commoners succeeded in winning over the ruler of the town in their opposition to Ibn 'Abd al-Salām's stance and, supported by a fatwā on the authority of the renowned Damascene scholar of law and hadìth Ibn al-Ṣalāh (d. 1245) - who suddenly revised his earlier attitude to the matter-, the prayer continued to take place. ${ }^{44}$ Abū Shāma wrote his treatise after this conflict and argued vehemently that the prayer was a repugnant innovation that needed to be stopped. The fact that Ibn Taymiyya vainly tried again some fifty years later to stamp out these prayers ${ }^{45}$ shows that Abū Shāma's attempts at stopping this practice were as unsuccessful as those of his teacher, Ibn 'Abd al-Salām.

Abū Shāma's focus on the issue of innovations followed a well-established literary genre especially common among writers of Maghribi and Andalusian origins belonging to the Māliki madhhab. ${ }^{46}$ However, his treatise was not merely a contribution to this genre; rather, he used it to spell out his concept of the need for continuous ijtihād. The $B \bar{a}^{\prime} i t h$ showed, with regard to a number of innovations, that only having recourse to the revelation could rectify a deviation from the 'original state' of the Prophet's time. In the text he almost exclusively used the revealed sources, and largely ignored later works.

A revivalist posture as defined above (a critique of the contemporary state of affairs in terms of a return to an idealized early Islamic period) takes perceived deviations from the 'original' state of affairs as an obvious target. It is in this field that Abū Shāma and other revivalists could clearly formulate the dichotomous notion of a complete break between past and present. At the same time, the choice of innovations as a subject for one of his works fitted his outlook on the status of later scholars. The very endorsement of such reprehensible innovations by respected scholars such as Ibn al-Șalāh underlined the deficiency of any statement besides the revelation. The dispute that arose surrounding the permissibility of the salät al-raghä'ib was itself a support for Abū Shāma's stress on the need to consult the revealed sources and lessen the authority of any later statement. This, because the disputes were not the outcome of different interpretations of the revelation, which he considered to be normal, but the result of a gradual process of falsification. This process had distorted the original intention of the revelation in such a way that even prominent scholars started to defend innovative practices like the salāt al-raghä'ib.

Abū Shāma's position was certainly a minority one in his time, as for him the process of ijtihād could never come to an end since no scholar could claim an authoritative status compared to Quran and sunna. His position shows, contrary to the middle position discussed above, that ijtihād in its classical sense had not entirely come to an end in later centuries. Abū Shāma understood the term ijtihā as a direct return to the revealed sources. Although he certainly advanced no claims to founding a new madhhab, he refused to accept that the later authorities, such as the founder of the madhhabs, had an all-embracing hegemonic position. He advocated an interpretation of ijtihäd

${ }^{44}$ Abū Shāma, al-Băcith, 45 f. The affair was also mentioned in the mujtahid list by the nineteenth-century revivalist al-Sanūsī, discussed below, when he named Ibn al-Ṣalāḥ (al-Sanūsī, $\bar{I} q \bar{a} z$, 73).

${ }^{45}$ Although Ibn Taymiyya succeeded in banning the prayers between 1302-03 and 1306-07 they were finally reintroduced under popular pressure (Pouzet, Damas, 344).

${ }^{46}$ On the genre of treatises against innovations in general see Fierro, 'Treatises'; J.P. Berkey, 'Tradition, innovation and the social construction of knowledge in the medieval Islamic Near East', in Past and Present 146, 1995: 38-65; and R. Lohlker, "Unstatthafte Neuerungen" oder das Feld der religiösen Diskussion im Islam', in Zeitschrift der Deutschen Morgenländischen Gesellschaft 149, 1999: 221-44. On the regional and doctrinal background of the authors, see Berkey, 'Tradition', 4 and Fierro, Treatises, 210. 
that emphasized the need to disregard the opinions of these subsequent authorities. As other scholars have pointed out, the crucial question in this regard is not one of exclusivity but one of hegemony. ${ }^{47} \mathrm{It}$ is beyond doubt that taqlid was the dominant mood during this and subsequent periods. However, the continued existence of ijtihād in its classical sense - even though it was a minority position - might have crucial significance, and should not be excluded in absolutist terms. As with ijtihād Abū Shāma adopted a vigorous attitude to the closely linked issue of taqli d. In modern scholarship, taqli $d$ has generally been equated with following blind and associated with the idea of intellectual stagnation - as opposed to the more 'rational' ijtihād. However, recent work has reinterpreted the term, showing in particular its crucial and vital function in the post-formative period ${ }^{48}$ and depicting it as the reasoned and highly calculated insistence on abiding by a particular authorative legal doctrine' ${ }^{49}$ It was only with taqli $d$ that rules derived on the basis of ijtihād could spread further, a certain stability develop in the legal field and the legal schools gain clear contours owing to the growth of legal authority. Furthermore, religious scholars cannot be exclusively attached to one or other method, but were generally placed on a continuum between the poles of ijtihād and taqlìd. A juridical argumentation based exclusively on either of the two methods would be almost inconceivable..$^{50}$

Throughout Islamic legal history taqlìd was considered to be perfectly suitable for laymen who could not be expected to possess the required knowledge for individual decisions. However, in the scholarly context the term occasionally took on a defamatory meaning when applied to other jurist-scholars. Although not every jurist-scholar was expected to be a mujtahid, the term taqlid could indeed carry negative connotations. The use of this term did not criticize the fact of the acceptance of a decision, which was a normal and necessary practice, but referred to those scholars who had no insight into either the textual basis or the underlying reasoning. ${ }^{51}$

Despite this reinterpretation of taqlid in modern scholarship, and the ambiguity of meaning in its contemporary context, some scholars used it almost exclusively in their argumentation in the sense of 'blind following'. Abū Shāma, for example, delivered a sharp criticism of his period around what he perceived to be the mujtahid/muqallid dichotomy. He deplored the fact that scholars of his time blindly imitated their respective school founder or other outstanding figures, a practice that had arisen within the law schools over the centuries. Referring to the scholars of his time he stated, 'taqlid has blinded him and deafened him so that he cannot hear the useful knowledge'. ${ }^{52}$ Although the actual legal practice was more complex, Abū Shāma perceived his contemporary scholarly community to be divided into the two groups of mujtahids on the one hand and muqallids on the other. For him this division amounted to a zero sum game, since in the post-formative period 'the mujtahids became few and the muqallids many'. ${ }^{33}$

\footnotetext{
${ }^{47}$ Jackson, Law and the State, $77 \mathrm{f}$.

${ }^{48}$ Ibid., 79-83; Calder, 'Al-Nawawì's typology' at: 151 f.; M. Fadel, 'The social logic of taqlìd and the rise of the mukhtasar', in Islamic Law and Society 3, 1996: 193-233; W.B. Hallaq, Authority, Continuity, and Change in Islamic Law (Cambridge, 2001), 86-120.

${ }^{49}$ Hallaq, Authority, IX.

${ }^{50}$ See, for example, the analysis of Ibn Taymiyya's argumentation based on a mixture of taqlid and ijtihàd in B. Jokisch, Islamisches Recht und Praxis. Analyse einiger kaufrechtlicher Fatwas von Taqī 'd-Din Ahmad b. Taymiyya, (Berlin, 1996), 205-51.

${ }^{51}$ Hallaq, Authority, 87.

${ }_{52}$ Abū Shāma, al-Mu'ammal, 68.

${ }^{5}$ Ibid., 42.
} 
According to Abū Shāma, taqlīd and the importance attached to the madhhabs were the reasons for the deviation in his own time from 'the Original State'; contrary to the Damascene faqì al-Nawawī (d. 1277) and others, he did not find any positive connotations to be associated with taqlid. Indeed, he considered it a dangerous development where the acceptance of the respective authorities in the madhhabs distorted and even replaced the revelation. Concerning the development of madhhabs he stated: "A knowledgeable man was asked about the meaning of "madhhabs". He answered that it means "a substitute religion". ${ }^{54}$ At the same time, he accused scholars who rejected the idea that mujtahids would continue to exist of deviation from revelation. ${ }^{55}$

Abū Shāma's polemics against the muqallids are also found in his book on the quranic sciences, Al-Murshid al-wajīz ilā 'ulüm tata'allaqu bi-l-kitāb al-'azìz (The Concise Guide to the Sciences Linked to the Venerable Book). In it, he argued against the muqallids, who blindly accepted that the seven traditional readings of the Quran were all mutawätir, that is, excluding error or forgery due to multiple chains of transmission. He questioned the authority of these readings, stating that they contained contradictions and mistakes, and cited a number of examples where grammarians had shown that certain readings were impossible. ${ }^{56}$ By this Abū Shāma reaffirmed his belief in the deficiency of scholars in the aftermath of the 'original state'.

Although this opinion of the readings was widely held, the clarity with which he expressed it actually incurred the censure of later scholars. For instance, the fourteenth-century Quran reader al-Jamālì stated that: '[t]his book has to be destroyed so that it does absolutely not appear [once again]. It is a slandering of faith'. ${ }^{57}$ Al-Jamālī's student, the great hadith scholar and Quran reader Ibn al-Jazarī agreed with him and accused Abū Shāma of questioning the authenticity of the Quran itself. ${ }^{58}$ This view of Abū Shāma's work was apparently not limited to those scholars: the relevant folios of this section were removed from two of the three manuscripts of this work preserved in Istanbul. ${ }^{59}$

\section{Comparative perspective: eighteenth-and nineteenth-century revivalism and ijtihād}

The issues discussed above with regard to Abū Shāma's understanding of ijtihād and taqlìd allow parallels to be drawn with eighteenth- and nineteenthcentury revivalists. The concept of ijtihād has been highly flexible and the meaning of the term has shifted from writer to writer; nor did the revivalists of the eighteenth and nineteenth centuries have a unified understanding of what the term meant. Their minimum consensus was the rejection of taqli $d$ in the sense of madhhab factionalism as being an innovation. However, significant differences appear in discussing further elements. These differences can be seen in the function of the varying positions taken vis-à-vis the traditionalist point

\footnotetext{
${ }^{54}$ Ibid., 36: 'wa-qad su'ila ba'ad al-'ärifin 'an ma'nā al-madhhab fa-ajāba anna ma'nāhu dìn mubaddal'

55 Ibid., 42.

56 'A. A bū Shāma, al-Murshid al-wajīz ilā 'ulūm tata'allaqu bi-l-kitāb al-'azìz, ed. Altıkulaç (Beirut, 1975), $173 \mathrm{ff}$.

${ }^{57}$ M. Ibn al-Jazarī, Munjid al-muqri' īn wa-murshid al-țālibīn, ed. 'A. b. M. al-'Imrān (Mecca, 1998/99), 199, citing Muhammad b. Muhammad al-Jamālì (d. 1382): 'Yanbaghì an yu'dama hàdhā al-kitāb min al-wujüd wa-là yaẓhara al-batta wa-annahu ța'n fì al-dīn'.

${ }^{58}$ Ibid., 209.

${ }^{59}$ Editor's introduction, Altıkulaç, al-Murshid. The relevant manuscripts are: Ayasofya 59 and Şehit Ali 2751.
} 
of view. ${ }^{60}$ A traditionalist understanding of ijtihād tends to narrow down the scope of the term by arguing that the later juridical works are largely sufficient to solve newly arising problems.

Al-Shawkānī was the most emphatic author to claim that each generation possessed the ability and sources for unlimited ijtihād. He was strongly opposed to taqlid and argued that laymen had easy access to mujtahids, who existed in every town in the Islamic world. He continuously emphasized the need for direct and unmediated access to the revealed sources. ${ }^{61}$ Al-Sanūsī, on the contrary, adopted the differentiation between independent and affiliated mujtahids, which allowed him implicitly to acknowledge the authority of the founders of the schools of law. Nevertheless, he also stressed their fallible nature and delimited them clearly from the authority of the revealed sources. ${ }^{62}$ Shāh Walī Allāh explicitly emphasized that Muslims were bound to accept the rulings of the four school founders. When he referred to ijtihäd in treatises such as al-Inșäf and 'Iqd, polemics against madhhab factionalism, for example, were absent. He adhered, furthermore, to the differentiation into different degrees of mujtahids as introduced by al-Nawawī. ${ }^{63}$ Finally, 'Abd al-Wahhāb hardly wrote on the issue of ijtihād. Hamad b. Nāsir b. Mu'ammar (d. 1810), the principal early Wahhābi author on this subject, argued for a taqlīd mixed with elements of ijtihād, which in this regard made the Wahhäbis the most conservative movement among the eighteenth- and nineteenth-century revivalists. ${ }^{64}$

Abū Shāma's understanding was closest to al-Shawkānī's reading of the term in the far-reaching application they both advocated. They were opposed to more moderate forms of $i j t i h \bar{a} d$ that accepted the traditionalist emphasis on the authority of the schools' founders. Al-Shawkānī and Abū Shāma represented, in contradistinction to this moderate/traditionalist ijtihâd, what one might call a revivalist understanding of it. This common outlook is also visible in certain arguments that can be found in both Abū Shāma and al-Shawkānī. For instance, each similarly dismissed the argument concerning an end to the process of ijtihād with a reference to the more propitious conditions in the present due to the compilation of hadith collections. While earlier scholars had to assemble the hadiths in a complicated process, later scholars had these readily to hand. Thus, according to Abū Shāma, 'to attain ijtihād after the collection of the hadiths in the approved books [...] is more convenient than before'. ${ }^{65}$ And after describing the large amount of scholarly work in the centuries following the Prophet, al-Shawkānī likewise argued that 'the ijtihād for the successors is easier and more convenient than the ijtihäd of the earlier generations'.66

The ways in which ijtihād traditions were transmitted between the thirteenth and eighteenth centuries are far from clear. A writer such as al-Sanūsī, for example, stated that al-Suyūtî in the sixteenth century had been the last to advocate a claim for ijtihād. ${ }^{67}$ Whether writings of earlier scholars such as Abū

${ }^{60}$ Peters, 'Idjtihād and taqlīd', is the most comprehensive overview on this issue.

${ }^{61}$ Haykel, Revival and Reform, 96-102.

${ }^{62}$ Vikør, Sufi and Scholar, 271.

${ }^{63}$ For example Shāh Walī Allāh, "Iqd', 349.

${ }^{64}$ Steinberg, Saudi-Arabien. The early Wahhābi stance on ijtihād remains to be studied in more detail especially since relevant studies such as Dallal 'Origins' do not take into account 'Abd al-Wahhāb's as yet unpublished treatise on this issue, Risāla fì mabhath al-ijtihād wa-l-taqlìd.

${ }_{65}$ A bū Shāma, al-Mu'ammal, 55: 'fa-l-tawașșul ilā al-ijtihād ba'd jam' al-sunan fì al-kutub almu'tamada [...] ashal minhu qabla dhālika'.

${ }^{66}$ Al-Shawkānī, Irshād, 254: 'fa-l-ijtihād 'alā al-muta'akhkhirīn aysar wa-ashal min al-ijtihād 'alā al-mutaqddimin'.

${ }^{67}$ Al- Sanūsì, 'İqāẓ', 74. 
Shāma played a direct role in the thought of later revivalists or were taken up via intermediate writings cannot be clarified in the framework of this article. The lists of mujtahids established by the later revivalists show at least that they had an awareness of their predecessors. The example of Abū Shāma proves that these lists were not simply discursive devices employed to enhance their legitimacy, but referred to meaningful examples.

\section{The societal context of claims for ijtihād}

Having established the existence of a pre-eighteenth- and nineteenth-century ijtihäd tradition, which resembled the revivalist reading of the term, the question arises as to what extent this tradition was connected to a critical and oppositional stance against considerable sections of contemporary society. In other words are we dealing with a mere technical similarity limited to the juridical field or with a similarity that is also relevant to the social context in which it was employed?

Revivalism during the eighteenth and nineteenth centuries was not always synonymous with an adverse relationship to the respective worldly authorities. Al-Sanūsī was not in general in conflict with the ruling elite of the places where he went, ${ }^{68}$ and al-Shawkānī's high position as chief judge of the imāmate prove his rather harmonic relationship with the Yemeni authorities. Yet they formulated a critique of the present in terms of reviving the early and ideal period of Islam. The rejection of later scholarly authorities in the juridical field was in this way linked to their disdain for the state of affairs in any period following what they perceived to be the Golden Age. Owing to this revivalist outlook the groups shared a similar discursive position within the different societies in which they acted: their political and activist outlook often pitched them in opposition to more traditionalist religious scholars ${ }^{69}$ and, in the nineteenth century, against elites and intelligentsias embracing an Islamic Modernism. ${ }^{70}$

Consequently, the major conflict that al-Sanūsì engendered brought him, during his stay in Egypt, into conflict with traditionalist scholars at the Azhar. The conflict turned around the issue of $i j t i h \bar{a} d$ and more specifically focused on the question of the school founders' position. The Azhar scholars al-Būlāqi (d. 1846) and 'Illaysh (d. 1882) issued fatwās attacking him for questioning the absolute authority of these early scholars. Al-Sanūsī had stressed the school founders' learnedness, but he also repeatedly underlined their fallibility. ${ }^{71}$

At the same time al-Shawkānī's position must be put into the context of the imàmate's history in Yemen during his period. The reorientation of the ruling house away from the hitherto dominant Zaydi tradition towards Sunni scholars, during the second half of the eighteenth century, set it partly in opposition to important parts of the Yemeni scholarly community. In this context al-Shawkānī and like-minded scholars were able to take a strong revivalist position towards their society and at the same time act in accordance with the ruling elites.

To address the above question, on the social environment in which pre-eighteenth- and nineteenth-century mujtahids acted, it is most fruitful to examine their respective discursive positions vis-à-vis their own societies. From the lists by al-Shawkānī and al-Sanūsī on previous mujtahids it appears that the majority of these individuals were well integrated into their contemporary

\footnotetext{
${ }^{68}$ Vikør, Sufi and Scholar, $241 \mathrm{f}$.

${ }^{69}$ Peters, 'Idjtihād and taqlīd'; Peters, 'Erneuerungsbewegungen', 90 ff.

${ }^{70} \mathrm{I}$. Lapidus, A History of Islamic Societies (Cambridge, 2002) (second edition), $457 \mathrm{ff}$.

${ }^{71}$ Vikør, Sufi and Scholar, 239-61 and Vikør, 'Development of ijtihad'.
} 
contexts and often held important posts. In al-Sanūsī's second part, of ten individuals described as being mujtahids, six were judges in Damascus, Egypt and al-Andalus ${ }^{72}$ but were not particularly renowned for their critical outlook on contemporary societies.

A similar connection between ijtihād and a strong integration into the established elite also existed during the Ottoman period: important Ottoman jurisconsultants, among them the sixteenth-century Sheyhülislam Ebu Suud, advanced a claim for ijtihād. However, with a few exceptions, this claim did not generally include direct and unmediated access to the revealed sources. It was less a revivalist understanding of the term than a slightly revised traditionalist version in a moderate vein. ${ }^{73}$ In what follows, I want to pursue the suggestion that mujtahids who were well integrated into their contemporary society tended to embrace moderate readings of ijtihâd, while those who stood in opposition to important sections of their contemporary society tended to embrace a revivalist reading. This will be done by turning to those in al-Shawkānı̄'s and al-Sanūsı̀’s lists who were well known for their critical stance vis-à-vis their society and worldly authority. Important members of the thirteenth- and fourteenth-century, predominantly Shäfi i, group in Cairo and Damascus linked their claim for ijtihād with a more general revivalist outlook. Among them were Ibn 'Abd al-Salām, Abū Shāma and the Hanbali Ibn Taymiyya.

Like Ibn Taymiyya, Ibn 'Abd al-Salām experienced the troubled career of an activist. He had a long-running conflict with the rulers of Damascus, which was described by a later writer under the telling heading 'Mentioning of what was at issue between the sultān of the scholars and al-Malik al-Ashraf'. ${ }^{74}$ The term 'sultān', used in juxtaposition to the lower-ranking title of 'malik', raised in this context the issue of whose authority was to be dominant: authority based on access to the revealed sources or authority based on worldly power. Ibn 'Abd al-Salām had a rather tense relationship with the town's ruler, in which, amongst other things, his claim for ijtihäd was an issue. ${ }^{75}$ During these conflicts the ruler temporarily confined him to his house with the added condition that he was not to meet anyone. He was finally arrested and expelled from the town after criticizing the ruler's policies towards the Crusaders. $\mathrm{He}$ was initially warmly welcomed in Egypt, and accepted posts such as khatī b. However, after destroying a building of the wazir's men on the roof of a mosque, he had to resign from the judgeship and was deposed from his position of khatī ${ }^{76}{ }^{76}$ In sum, his attitude to rulers was described in various sources as being such that 'he attached little importance to the $m u l \bar{u} k^{37}$ or 'he avoided to praise the mulük'. ${ }^{78}$

Let us now turn to this article's protagonist, Ibn 'Abd al-Salām's student Abū Shāma, in order to consider his social position in more detail. Abū Shāma was not descended from a prominent family. His great-grandfather Abū Bakr Ismā'īl moved to Damascus after his father Abū Bakr Muhammad had been killed in the conquest of Jerusalem by the Crusaders in 1099. While some of Abū Bakr Ismā'̄il's descendants had been learned men and had even taught, it

\footnotetext{
${ }^{72}$ Al-Sanūsī, 'Īqāz’, 73.

${ }^{73}$ Gerber, Law and Culture, whose intention is nevertheless to show that ijtihād was a continuing reality during the Ottoman periods.

${ }_{74}^{74}$ Al-Subkī, Țabaqāt, 8: 218 ff.

${ }^{75}$ Ibid., 8: 233.

76 Al-Dhahabì, Tārìkh, years 651-660: $416 \mathrm{ff}$.

${ }_{77}$ Al-Asnawī, Țabaqāt, 2: 197. 110 .

${ }^{78}$ Ibn Qāọī Shuhba, Ṭabaqāt al-Shāfi' iyya, ed. 'Abd al-'Alīm Khān, 4 vols. (Beirut, 1987), 2:
} 
was only with Abū Shāma himself that a member of the family gained prominence. ${ }^{79}$ There had been no marriage alliances with the leading families of Damascus such as the banū 'Asākir or banū al-Qalānisī. Furthermore, his family had settled in the eastern part of the town, close to the Bāb al-Sharqī, where he himself was born.$^{80}$ His house, in which he died, was outside the walls, to the north-east of the town. Neither location was inhabited by the town's notables, who lived within the walls, in the western part of the town. ${ }^{81}$

Both he and his family had close contacts with the Maghribi families who were themselves relatively marginalized in Damascus' social texture. Abù Shāma's mother, the second wife of his father, and at least one of his own wives came from Maghribi families. His daughter married within this community, and several of his children were buried in a cemetery often used by Maghribis. These marriage connections with the Maghribi community were not the norm in Damascene society. ${ }^{82}$

This link to the Maghribi community was echoed in Abū Shāma's scholarly outlook. Although he belonged to the Shaffi 'i school, in contrast to the mostly Māliki scholars from the Western lands, his writings were none the less influenced by the latter. For example, his treatise against innovations (bida) was in a genre mostly established by Western Māliki writers, as seen above. From al-Ṭurtūshì (d. 1126) he took over the crucial differentiation of innovations between those known as such and those considered to be religious duties. Al-T Turtūshī's treatise on this subject proved to be very influential after this Māliki author of Andalusian origin had settled in Egypt. ${ }^{83}$ Abū Shāma's close relationship with the Maghribi Māliki community was also visible in the ijāza (licence to teach) and $\operatorname{sam}_{\bar{a}}$ (certificate of attending a lecture) that he issued. Here again, the number of individuals with a Maghribi/Māliki background is remarkable. ${ }^{84}$

At first glance this marginalization contrasts with the different posts Abu Shāma held in the course of his life in Damascus: notary-witness (shähid) from 1237-38 onwards, ${ }^{85}$ imām in the 'Ādiliyya Madrasa ${ }^{86}$ and teacher in the Rukniyya Madrasa (1262). While these posts were all of minor importance, he attained in 1264, towards the end of his life, a more prestigious post, the headship of the Dār al-Hadìth al-Ashrafiyya. However, this did not belong to one of the fiefs of the grand Damascene families; its post-holders were generally from outside the town in contrast to the posts in institutions such as the Dār al-Hadīth al-Nūriyya, which was for example controlled until the middle of the thirteenth century by the banū 'Asākir. ${ }^{87}$

${ }^{79}$ Abū Shāma, Dhayl, 37 for information on his ancestors.

${ }^{80}$ Ibid., 37.

${ }^{81}$ Pouzet, 'Abu Shama', $116 \mathrm{ff}$.

${ }^{82}$ Pouzet, 'Damas', $171 \mathrm{ff}$

${ }^{83}$ Muhammad b. al-Walīd al-Ṭurțūshī (d. 1126), Fierro, 'Treatises', 208 ff.

${ }^{84}$ In a reading of his Book of the Two Gardens to Abu Shāma in 1265, for example, three of the six students attending belonged to this group: Ibn Farah al-Ishbili (Seville), Zayn al-Dìn al-Qurțubì (Cordova) and Ismā'īl al-Mālikī (notice reproduced in al-Zībaq edition, 3: 16).

${ }^{85}$ A bū Shāma, Dhayl, 167.

${ }^{86}$ Abū Shāma, Dhayl, 199, in the obituary notice for Shams al-Dīn Mahmūd (d. 1258), who 'replaced me in the ritual prayers in al-Madrasa al- 'Addiliyya during my absence due to illness or when I was in the gardens'. On this madrasa see 'A. al-Nu'aymī, al-Dāris fì tārīkh al-madāris, ed. J. al-Hasanī, 2 vols. (Damascus, 1948-51), 1: 359-67 (al-Madrasa al-'Ādiliyya al-Kubrā) and H. Shumaysānī, Madāris Dimashq fì al-'asr al-Ayyūbì , (Beirut, 1983), 129-35.

${ }^{87}$ Pouzet, Damas, 194-5; J.E. Gilbert, 'The Ulama of medieval Damascus and the international world of Islamic scholarship', (PhD Thesis, University of California Berkeley, 1977), University Microfilms (Ann Arbor), 203-04, argues that 'outsiders' had good chances to acquire posts in the town, as only around half were held by the grand families. Nevertheless, Gilbert does not differentiate between prestigious and minor posts, which would alter the rather harmonious picture of the 'international system of scholarship'. 
In addition, the period 1264-65 shows an Abū Shāma who differed significantly from previous and subsequent years: besides receiving the post in the Ashrafiyya, he led the funeral prayers of notable scholars. Among them were his predecessor Ibn al-Harastānī, a scion of a prestigious Damascene family, ${ }^{88}$ Zayn al-Dīn Khālid al-Nābulusī, the shaykh of the Dār al-Hadìth al-Nūriyya, and 'Abd al-Rahmān Ibn Sasrā, who held in the course of his life several influential posts in the town's administration. ${ }^{89}$ It seems that a temporary amelioration in the relationship between Abū Shāma and the town's more influential families occurred in this period. However, this peak in contacts with families of high social status was neither part of a long-standing social practice by Abū Shāma nor did it continue. It was an isolated period in the life of a rather marginalized individual who never came close to any of the prestigious and influential religio-political positions in the town, such as a judgeship or a khațīb-ship.

Abū Shāma omitted from his autobiographical section the endowed teaching positions he had held, as well as his entire Damascene chronicle, which contained important autodocumentary passages, avoided in general the issue of posts. He did so because he saw himself as an 'ideal/withdrawn scholar', generally avoiding contact with the worldly authorities of his time. This trait was stressed by students in a continuation of Abū Shāma's autobiographical passage: 'He was inclined to seclusion and withdrawal. He did not wish to frequent the doors of the people of this-world and thereby avoided competing for posts. ${ }^{90} \mathrm{He}$ expressed this view of himself by, for example, sharply criticizing contemporary scholars. He especially focused his criticism on post-holders such as judges, whom he accused of being ignorant and unjust. For instance, in 1265, when three chief-judges in Damascus were appointed all with the honorific title (laqab) Shams al-Dīn (Sun of the Religion), he approvingly cited these lines in his Damascene chronicle:

The people of Damascus are doubtful with regard to the large number of judges.

They are all suns but they [the people of Damascus] are in darkness.

and:

In Damascus a miracle appeared to the people in general:

Whenever a sun takes the judgeship the darkness intensifies! $!^{91}$

${ }^{88}$ Abū Shāma, Dhayl, 229-30. On 'Abd al-Karīm b. 'Abd al-Samad Ibn al-Harastānī (d. 1264) see M. al-Yūnīnī, Dhayl mir'āt al-zamān (ed. n.n.), 4 vols. (Hydarabad, 1954-61), 2: 295 f.; al-Dhahabī, Ta’rìkh, years 661-670: 104 f.; al-Safadī, Wäfì, 19: 78 f.; al-Asnawī, Tabaqāt, 1: 446 f.

${ }^{89}$ Abū Shāma, Dhayl, 233 and 236. On the Șașrā family see W.M. Brinner, 'The banū Șașrā: a study in the transmission of a scholarly tradition', in Arabica 7, 1960: 167-95.

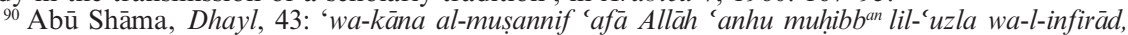
ghayr mu'aththir lil-taraddud ilā abwāb ahl al-dunyā, mutajannib ${ }^{a n}$ al-muzähama 'alā al-manāsib'. An image repeated in one of his poems cited by M. al-Kutubì, 'Uyūn al-tawä̀ìkh, ed. F. al-Sāmir and 'A. al-Mun'im Dā'ūd (Baghdad, 1980), 20: 354: 'I do not take refuge at a door other than his [God]'. ('wa-innan̄i lā alja'u ilā bāb ghayrihî̀. The autobiographical passage is in Abū Shāma, Dhayl, 37-9 with continuation by students up to page 45. See J.E. Lowry, 'Time, form and self: the autobiography of Abu Shama', in Edebiyât 7, 1997: 313-25; L. Pouzet, 'Remarques sur l'autobiographie dans le monde Arabo-Musulman au Moyen-Age', in U. Vermeulen and D. De Smet (eds), Philosophy and Arts in the Islamic World (Leuven, 1998), 97-106 and D.F. Reynolds (ed.), Interpreting the Self. Autobiography in the Arabic Literary Tradition (Berkeley/Los Angeles/ London, 2001), esp. 179-87.

${ }_{91}$ A bù Shāma, Dhayl, 236. 
He furthermore criticized them for serving the Mongols and for indulging in adultery and whoredom; he also exposed them to ridicule for pronouncing defectively the letters $\mathrm{R}$ and $\mathrm{Q} .^{92}$

Abū Shāma criticized in addition those scholars who were, as he saw it, too close to the power holders since they held positions financed by endowments, e.g. teacherships. ${ }^{93}$ In a poem in which he defended his decision to withdraw from teaching in the year 1262-63 and work his lands he addressed a fictive student with the words:

Do not compete and do not exceed in what you take

of it [i.e. the endowment] as you know the matter!

If you are needy, take the sufficient with aversion and with the determination that it will not last a life time!

Before us had been imāms of this religion and the endowment developed [only] later.

O student! This had not been a hindrance for knowledge, so follow this tradition! [...]

Whoever is free, eschews the alms of endowments which come to him with untroubledness and ease.

What is the state of the one who abases himself in word and deed in order to receive a little? [...]

Who sells his faith for someone else's worldly treasure, indeed, the vendor of the faith will be disappointed by the loss! [...]

May God save me from competing with the people for a post [manșab]. O God [give me] firmness! $!^{94}$

Abū Shāma's criticism of the present was closely connected to one of his recurring themes: the decline of his period in contrast to the period of the Prophet and the Prophet's companions. He stated, for example: 'The signs of knowledge have been wiped out. In this time its command and exact performance have become rare. Negligence led it to be not respected anymore. Its honouring and glorification have become rare'. ${ }^{95}$ While discussing the innovative prayers of his time, he showed how the companions of the Prophet had forbidden much lesser changes to the 'original state of affairs'. With regard to the contemporary state of affairs he could only ask with disgust 'and what would have been if the companions had seen what has been introduced of innovative prayers at reprehensible times in ways not prescribed by the

${ }_{92}^{2}$ Ibid., 225, 11. 2, 5 and 6. Another example of his criticisms of judges would be Ibn Kathīr's statement that Abū Shāma 'defamed and criticized' Aḥmad b. Yahyā Ibn Sanī al-Dawla (d. 1260), who held the chief-judgeship of Damascus for fifteen years. (İbn Kathīr, al-Bidāya, 13: 237: 'wa-lākinna Abū Shāma yanālu minhu wa-yadhummuhü').

${ }^{93}$ However, his opposition to posts financed by endowments was not unequivocal as he stated that the madrasas were an example of 'good innovations' [al-bida' al-hasana] (Abū Shāma, al-Bä́ith, 23).

${ }_{94}$ Abū Shāma, Dhayl, 223, 11. 23-5; 224, 1, 3/4, 7; 226, 8:

là tuzāhim wa-lā tukāthir bi-mā ta'khudhulminhu fa-qad' 'arafta 'l-amrāa wa-in ihtajta khudh kafäfan bi-karh' $/$ wa-bi-'azm in an là yadüma 'l-'umrā

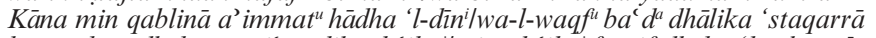

lam yakun dhāka mānican țālib'a al-'ilmi/min al-'ilm' fa-qif dhāka 'l-atharā [...]

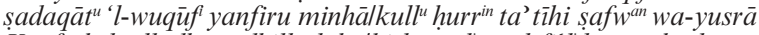

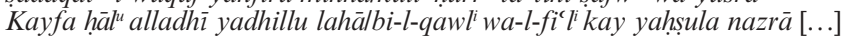

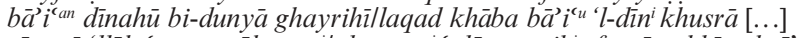

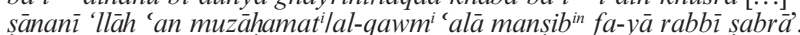

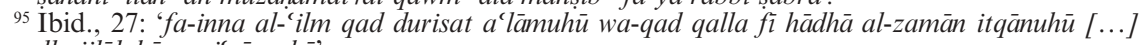
wa-qalla ijlāluhù wa-i' żàmuhü'. 
revealed law, the forgery of hadiths and the stubborn resistance to the people of the truth among the religious scholars who contested them?'96

The reasons for the decline in his period were laziness among scholars and, more importantly, the love of this world. It is his stance towards the issue of holding posts that reappeared here. He cited, for example, an earlier scholar, who had deplored the decline in his period by criticizing scholars who 'submitted their knowledge to the rulers and the people of this-world, who oppressed them and scorned them'. ${ }^{97}$ This criticism of holders of posts went hand in hand with his aversion to muqallids, which he attacked in similar terms. While he described the muqallids as being blind and deaf to useful knowledge (cited above), he stated in his long poem, justifying his 'withdrawal' into work that 'the love of this-world makes blind and deaf'. ${ }^{98}$ The deplorable present state was consequently because of scholars who preferred to pursue worldly ends thereby neglecting the pursuit of real divine knowledge, in contrast to Abū Shāma:

those who are close to the Grandees [akäbir], still serving, extolling and praising them;

seeking their glory and indulging insistently in obedience to all their affairs.

Thus, you see the chief-judge and the teacher complying with him secretly and overtly ${ }^{99}$

It is here that Abū Shāma's understanding of ijtihād and taqlìd most clearly played a role with regard to the question of authority. He could not only represent these scholars as being too orientated towards the values of this world, but could also question their authority in general by undermining their right to express qualified opinions on legal matters. For instance, he expressed this questioning of other scholars' authority by repeatedly citing the hadith that the Prophet feared most for his community from wrongly guided imāms. ${ }^{100}$

Abū Shāma's rather controversial nature was exemplified by his death in 1267 at the age of 66. Abū Shāma himself referred in his Dhayl to two men who had entered his house under the pretext of demanding a juridical opinion (fatwa) and had beaten him severely. It would seem that nobody came to his help ${ }^{101}$ and he died some months later, possibly after the same two men had returned once again. A number of sources attributed the murder to conflicts within the town. ${ }^{102}$ Ibn Kathīr (d. 1373), for example, stated that Abū Shāma had been accused of $r a^{3} y$, i.e. basing his juridical opinion on his own judgement and not on the acknowledged procedures of jurisprudence. This accusation meant that he was perceived as having transgressed the generally accepted limits of ijtihäd of his period. Given the different contemporary understandings of $i j t i h \bar{a} d$, this accusation arguably referred to the contentious issue of sources. Abū Shāma's method of discussing legal points by ignoring later authorities

${ }^{96}$ Abū Shāma, al-Bā'ith, 71 f.: 'fa-kayfa law ra'à al-ṣahāba mà qad uhditha min hàdhihì al-ṣalawāt al-mubtada'a fì al-awqāt al-makrüha 'alā al-sifāt ghayr al-mashrū'a thumma wudì'a fìhā ahādīth munkara thumma 'ünida fìhā man ankarahā min ahl al-haqq min al-'ulamä's'.

${ }_{97}$ Abū Shāma, al-Mu'ammal, 34 citing Wahb b. Munabbih al-Yamānī (d. 732): 'fa-țarahū 'ilmahum 'alā al-mulūk wa-ahl al-dunyā fa-ihtadamūhum wa-ihtaqarūhum'.

${ }_{98}$ A bū Shāma, Dhayl, 224, 1. 16.

${ }^{99}$ Ibid., 222, 11. 14-16.

${ }^{100}$ For example Abū Shāma, al-Bāeith, 56.

${ }_{101}$ Al-Safadī, al-Wāfì, 18: 113-16 and al-Asnawī, Tabaqāt, 2: 118, 119.

${ }^{102}$ Ibn Kathīr, al-Bidāya, 13: 264 ff. (d. 1373); M. al-'Aynī, 'Iqd al-jumān fì tārīkh ahl al-zamān, ed. M. Amīn (Cairo, 1987, not completed), 2: $13 \mathrm{ff}$. (d. 1451) states that he was accused of an 'affair'. 
and focusing instead on the revealed sources was beyond the norm for his period.

It is ironic that Abū Shāma himself strongly rejected $r a^{\prime} y$, putting it forth as another reason for erring belief. He accused his contemporaries of $r a^{\prime} y$, too, as they decided cases without recourse to the revealed sources, what he terms $i j t i h \bar{a} d b i-l-r a^{\prime} y$ - a line of reasoning unacceptable after the establishment of the two sources. ${ }^{103}$ According to Abū Shāma, the sources used by his contemporaries were mostly either completely unrelated to the revelation or, more importantly, distorted due to their later nature. He cited in a section on $r a^{\prime} y$ approvingly the first-century saying 'If you receive a report from the companions of Muhammad then venerate it (lit.: put it on your head), if you receive one of the following generation strike with it the back of their heads' ${ }^{104}$

In the case of Abū Shāma the link between a revivalist understanding of ijtihād and taqlìd and the question of social authority is particularly manifest. ${ }^{105}$ By lowering the status of earlier writers and criticizing many of his contemporaries, he laid a claim to authority for scholars who were, according to him, able to redress the current deplorable state of affairs. The accusation of taqlid implied an exclusion of the majority of contemporary scholars from the group qualified to guide society. Thus, Abū Shāma's insistence on having recourse to the revealed sources each time and his distrust of later scholarly authorities was closely connected to his perception of his own society.

Abū Shāma's outlook brought him into conflict with influential groups in the town, such as the commoners and more traditionalist religious scholars. His career was less troubled than those of Ibn 'Abd al-Salām and Ibn Taymiyya only because he did not engage in activism in order to implement his convictions. He was rarely in conflict with the ruling elite, which he avoided completely, and instead focused his criticism on the scholarly community. All the same, his problems in Damascus, which culminated in his violent death, support the link suggested above between a revivalist reading of ijtihād and an oppositional stance towards important sections of contemporary society.

\section{Opposition to mysticallpopular religious practices}

The link between Abū Shāma and later revivalists was not limited to the issue of ijtihàd, but also included the position taken against certain mystical and popular practices, which could be broadly described as Sufi. Here again important differences are evident within the eighteenth- and nineteenthcentury movements. Individuals such as al-Sanūsī and Shāh Walī Allāh, for example, were deeply rooted in a mystical outlook. Ibn 'Abd al-Wahhāb on the contrary, rejected out of hand mystical practices and beliefs and orient his revivalist efforts mainly towards their suppression. Nevertheless, even those individuals who emerged from a Sufi environment strove to limit practices and beliefs that they considered to be exaggerated. ${ }^{106}$ This opposition varied in

${ }^{103}$ Abū Shāma, al-Mu'ammal, 38f.

${ }^{104}$ Ibid., 44 citing again 'Âmir al-Sha'bī (d. 721).

${ }^{105}$ On the link between authority and ijtihād in general, see Vikør, Muhammadan Piety, $21 \mathrm{f}$.

${ }^{106}$ It is doubtful whether it is possible to follow the argument by Rahman, Revival and Reform, on the development of a new trend in Sufism, 'Neo-Sufism'. This argument has been taken up with reservations by scholars such as Voll (Linking Groups, 83 f.). Several students of mystical trends in this period reject the notion of a qualitatively new Sufi trend on a large scale, e.g. B. Radtke, 'Erleuchtung und Aufklärung: Islamische Mystik und Europäischer Rationalismus', in Die Welt des Islams 34, 1994: 48-66. 
intensity, with Ibn 'Abd al-Wahhāb, in his outright rejection, being the exception. However, the attitudes of the revivalists to ideas like those of Ibn 'Arabì are still far from being explained in detail. ${ }^{107}$

Abū Shāma's historical context was markedly different, as no organized mystical brotherhoods had yet emerged. However, outstanding mystical thinkers also played a role in his home town. For example, Ibn 'Arabī, whose mystical thinking was to be influential in the following centuries, died in Damascus in 1240. Abū Shāma strongly criticized practices that he perceived to be outside the realm of the acceptable. In his treatise against the salāt al-raghä'ib, Abu Shāma accused 'the groups of those inclined to poverty', a reference to mystical and ascetic groups 'who are in reality [only] poor in their belief', of illicit relations with women, breaking rules of fasting and neglecting the prayers. According to Abū Shāma, these practices were also the bases for pagan practices of unbelief like idolatry. He especially deplored the veneration of specific places, such as springs, trees and stones, in the belief that it might lead to recovery from illness or fulfilment of wishes. ${ }^{108}$ For Abū Shāma these practices formed an entity with 'popular' practices such as the innovative salät alraghä'ib, which had to be stopped. Later authors, holding a position in their societies similar to that of Abū Shāma (such as the Hanbali student of Ibn Taymiyya and mujtahid Ibn Qayyim al-Jawziyya (d. 1350)), quoted such sections at length. ${ }^{109}$

\section{Conclusion}

This article has argued that revivalist ijtihād, a crucial element in the thought of eighteenth- and nineteenth-century revivalists, can be traced back to earlier examples. The history of ideas is always connected to the question of quantitative relevance. If previously existing ideas, which were not originally taken up by the societies in which they originated, do become current at a later date, an important change has indeed taken place. The revivalist stance of Abū Shāma and other like-minded individuals had not been able to impose itself as the dominant concept in its period. Even a major thinker like Ibn Taymiyya was sidelined within his own Hanbali madhhab on the issue of ijtihäd. During the following centuries it was actually the moderate tradition within Hanbalism, represented by 'Abd Allāh Ibn Qudāma (d. 1223), that was dominant. ${ }^{110}$ It needed the acute mood of crisis and failure in the eighteenth and nineteenth centuries to bring their ideas to the foreground in order to confront new problems. It appears that these 'new' concepts were essentially continuous strands of revivalism. The change that took place during this period was not one of a shift to a completely new set of ideas, but one of a changed historical context in which previously existing ideas were now able to impose themselves. ${ }^{11}$

The present findings show the need to consider the hitherto neglected 'decline' period in more detail in order to gain an understanding of subsequent

${ }^{107}$ Knysh, 'Ibrāhīm al-Kūrānī’, 47.

${ }^{108}$ A bū Shāma, al-Bā'ith, 25 f.: 'țawä’ if min al-muntamīn ilā al-faqr'. He specifically named here, for Damascus a spring, a pillar and a tree at the Tūmā, al-Ṣaghīr and al-Nașr gates respectively.

${ }^{109}$ For example: Ibn Qayyim al-Jawziyya, Ighāthat al-lahfän min mașāid al-shaytāan, ed. n.n. (Beirut, 1983?), 1: 164.

${ }^{110}$ Steinberg, Saudi-Arabien.

${ }^{111}$ Similarly, Kuhn shows in his reflection on paradigmatic changes in science that concepts often remain on an unarticulated level for a period. They gain force only when problems arise that cannot be solved by existing paradigms. It is in this moment of crisis that previously developed concepts are taken up to confront the changed state of affairs (T.S. Kuhn, The Structure of Scientific Revolutions, $2^{\text {nd }}$ ed. (Chicago, 1970), 74 f.). 
developments. A number of questions raised in this article will be answered only by looking at the issue in a larger framework. Most importantly, the scholars included in the lists of the eighteenth- and nineteenth-century revivalists have to be considered under questions similar to those raised in this article: what kind of ijtihäd was advanced (moderate or revivalist)? In which societal context was this claim advanced (e.g. the issue of integration into contemporary society)? In addition, individuals and movements that do not appear in these lists but share a similar outlook have to be included: a minor example of such movements would be the suppressed religious riot in Cairo at the start of the eighteenth century centred on a student of religion who implicitly claimed ijtihā $\bar{d}$ and strove to suppress certain Sufi practices. ${ }^{112}$ Finally, it has to be asked whether the practice and thought of revivalist individuals and groups did indeed play a direct role in subsequent periods.

Such a comparative study of 'revivalist' movements and their historical contexts prior to the 'grand' movements would allow definition of commonalities and particularities in the way opposition to the respective state of affairs was expressed at different points in Islamic lands.

${ }^{112}$ R. Peters, 'The battered dervishes of Bab Zuwayla. A religious riot in eighteenth-century Cairo', in Levtzion and Voll (eds), Eighteenth-century, 93-115. 